\title{
INTERJÚ NEIL SMITH EGYETEMI TANÁRRAL az amerikai földrajz és a feminista geográfia néhány kérdésérôl
}

\author{
(Interview with Neil Smith \\ about some questions of American and feminist geography)
}

Neil Smith a Rutgers Egyetem (New Brunswick, NJ, USA) Földrajz Tanszékének vezetôje, a posztgraduális képzés igazgatója, több nemzetközi folyóirat szerkesztóbizottságának tagja. Városföldrajzot, humángeográfiai elméleteket, földrajztörténetet, sốt idónként természetföldrajzot is tanít. Legfontosabb kutatási témái: az urbán geográfia (s azon belül elsósorban a dzsentrifikáció vizsgálata); a egyenlótlen területi fejlôdés; a földrajz története, melynek keretében jelenleg Isaiah Bowman munkásságáról ír könyvet. Annak ellenére, hogy még 40 éves sincs, egy $1986-90$ között a társadalomföldrajzi szakirodalomról végzett felmérés szerint a világ 14. legtöbbet idézett geográfusa. Ez valószínúleg részben annak köszönhetổ, hogy mindhárom eddigi kutatási területén átfogo, általános elmélet kifejlesztésére törekedett.

Míg Észak-Amerikában vagy Nyugat-Európában a földrajzon belül számos paradigma él egymás mellett, s többnyire az egyes kutatókról is köztudott, hogy melyik irányzat hivei, Magyarországon ez a fajta sokféleség még nem alakult ki, vagy nem vált nyilvánvalóvá. Ön hogyan lett az általában David Harvey nevével fémjelzett nyugati neomarxista ,iskola" tagja?

Annakidején a skóciai St. Andrews Egyetem hallgatójaként matematikát és földrajzot kezdtem tanulni. Szórakoztatott ugyan a matematikai feladatok megfejtése, de ennél valami sokkal kézzelfoghatóbb eredményre vágytam, ha úgy tetszik, társadalmi hasznát szerettem volna látni a munkámnak. Érdeklődésem fokozatosan a természetföldrajz felé fordult, részben mert ott a matematikai ismereteimnek is hasznát vehettem - például a glaciális tevékénység modellezésében -, részben pedig, mert elbũvölt a szemem elốtt kibontakozó, jég által formált táj. 1974-ben aztán egy ösztöndíj segítségével kijutottam az USA-ba, Philadelphiába. Ott szinte bénítólag hatottak rám azok a rendkívül nagy társadalmi egyenlốtlenségek, melyek az egész város arculatát meghatározták; azok az osztályok, fajok, etnikumok között húzódó éles határok, melyeket a kapitalista társadalom - természetföldrajzi hasonlattal élve - a ,tájba vésett”. Az 1960-as évek végének eseményei engem is erốsen radikalizáltak, $\mathrm{s}$ Amerikában végre megtaláltam azt a kutatási területet, ahol politikai szándékaim és intellektuális igényeim találkozhattak. \$zociális érzékenységem és szakmai érdeklôdésem egyaránt azt követelték meg, hogy - a városi tér differenciáltságának vizsgálatán keresztül - mélyreható magyarázatot találjak az emberi társadalom téralkotó tevékenységének mikéntjére. Ekkor olvastam el David Harvey 1973-ban publikált, ,,Social Justice and the City” (Társadalmi igazságosság és a város) c. könyvét. Nagy hatással volt rám, $s$ bár erôsen vitattam az általa javasolt marxista elemzések jelentôs részét, ugyanakkor azt is éreztem, hogy az engem érdeklơ kérdéseket ó sokkal teljesebben vizsgálta meg, sokkal messzebbre jutott azok megválaszolásában, mint bárki más, akit ismertem. Mire 1977-ben ösztöndíjat kaptam a Johns Hopkins Egyetemre (hogy Harvey közelségében írhassam 
meg Ph.D disszertációmat), egyre jobban meggyổzôdtem arról, hogy ha az ember visszanyúlik az eredeti Marxhoz, Leninhez, Trockijhoz, ha az eredeti, és nem valamiféle sztálini verzióját olvassa az ổ mû́veiknek, vagy pl. Gramsci, Lukács írásainak, azokban hihetetlen mennyiségư társadalmi információt, elméleti tételt, kifinomult magyarázatot talál a kapitalista társadalom müködésére vontkozóan.

Ön, aki az USA-ban és Európában is élt és tanult, talán jobban meg tudja itélni azt, hogy mivel magyarázható az amerikai geográfiának a világ más részein müvelt földrajzra gyakorolt jelentôs hatása?

Nem hiszem, hogy az amerikai geográfia olyan befolyásos lenne. Az mindenesetre elgondolkodtató, hogy még így is sokkal nagyobb a hatása az országon kívül, mint azon belül. Tagadhatatlan - $\mathrm{s}$ engem is ez vonzott ide -, hogy az USA-ban egy valóban széleskörũ, energikus, stimuláló intellektuális vita folyik a tudósok között. Ennek ellenére a tudományos világ, leszámítva a technológiát és olyan területeket, mint pl. a fizika vagy a mû́szaki tudományok, általában véve nem fejt ki jelentốs társadalmi hatást az USA-ban. Különösen, ha valaki kritikus értelmiségi - ami jelen esetben az amerikai rendszer, az amerikai kapitalizmus bírálatát jelenti -, akkor ugyan bizonyos határon belül megengedik neki, hogy azt mondjon, amit csak akar, de ennek semmilyen hatása sincs. Ahogyan Herbert Marcuse nevezte: ez az ,,elnyomó tolerancia" - vagyis az ellenzéki eszmék tolerálása olyan nagyfokú, hogy az már elnyomóvá válik. Ugyanakkor a MÉDIA sokkal erôsebben ellenôrzött, mint bizonyára bárhol másutt Nyugat-Európában. Én legalábbis sehol sem láttam olyan antiintellektuális sajtót, mint itt. A sajtó azok számára szabad, akik azt megengedhetik maguknak. Azok számára, akiknek nincs elég pénzük, szabad ugyan, csak éppen hozzáférhetetlen.

Végül magának a földrajznak a kifejlôdése is hozzájárult ahhoz, hogy a brit geográfia sokkal befolyásosabb az amerikainál. Az elốbbi már a XIX. században intézményesítette önmagát, és a különbözổ diszciplínák között akkoriban fennálló nagy versenyben elismert pozíciót vívott ki magának, $s$ azt meg is tartotta. Ezzel szemben az USA-ban a földrajz csak a XIX. sz. végén, a XX. sz. elején kezdett keresni valamiféle garanciát a tudományos státusz elnyeréséhez. Úgy tûnt, a földrajzi determinizmus jelenti az utat a tudomány felé - ez természetesen tragikus zsákutcának bizonyult. Ugyanakkor az Amerikában oly fontos földrajzi felfedezések révén a geológia jutott jelentốs szerephez. Így részben ennek, részben a földrajzi determinizmus ideológiai bukásának köszönhetổen, azon kérdések fölött, melyekre Európában a természetföldrajz adta meg a választ, itt a geológia diszponált, míg a társadalomföldrajzi problémákat az antropológia kezelte. Azt hiszem, leginkább ezen tényezőkkel magyarázható, hogy a XX. században megjelenõ amerikai geográfia meglehetôsen gyenge maradt, amit nem is hevert ki igazán. Talán optimistának tũnök, de szeretném hinni, hogy az elmúlt 20 évben megindult egy ,,felépülési folyamat”. Ami itt az 1970-es évek eleje óta a geográfiában történik, az szinte páratlan az amerikai társadalomtudományok viszonylatában: egy tanulási ,láz”, különböző megközelítési módok keresése. Ez a marxista munkákkal indult el, majd a feminista kutatásokban, $\mathrm{s}$ a legkülönfélébb társadalomelméletekben teljesedett ki. Egy rendkívüli szellemi ,erjedésnek" lehetünk tanúi, s azt hiszem ez az, amire a folyóiratokon keresztül felfigyeltek Európában. De még egyszer hangsúlyozom: ez nem jelenti azt, hogy a földrajznak az USA-ban befolyásos pozíciója van. 
Gondolom, ennek a szellemi pezsgésnek egy megnyilvánulása a kutatási témák szinte hihetetlenül széles skálája. Elegendố bepillantanunk az Amerikai Geográfusok Társasága legutóbbi konferenciájának programjába. A munkacsoportok témái között a kulturális ökológiától a nókról alkotott nézetek tanulmányozásán át a biblia földrajzának kutatásáig szinte minden megtalálható. Attól tartok, Magyarországon egy olyan témát, mint pl. , New York ábrázolása a XX. századi gengszter filmekben" nem is fogadnának el fóldrajznak. Ez a myitottság egyúttal jó kapcsolatot is jelent más diszciplínákkal?

Azt hiszem, néhány kimondottan tradicionális kutatóhelytốl eltekitve, az amerikai geográfia végre felhagy annak vizsgálatával, hogy tulajdonképpen mi is a földrajz. Így elkerülhetô az a nagyfokú zártság, ami a közgazdaságtant és a politikatudományt, az USA manapság két legdiktatórikusabb diszciplínáját jellemzi. Ezek azok a tudományágak, melyek a rendkívül erốs versenynek kiszolgáltatva pontosan megmondják nekünk, hogy mit gondoljunk a közgazdaságtanról, hogy mit gondoljunk a politikáról. A mi diszciplínánk képviselői viszont egyrészt nem tartják ilyen fontosnak a versenyt, másrészt senki sem tudja igazán, mi is a geográfia. Ezért aztán senki sem írhatja elổ, mi az, amit földrajzként mũvelnünk kell. A legizgalmasabb eredmények ma a társtudományokkal összekötố határterületeken születnek. Edward Soja könyvének alcímét (The reassertion of space in critical social theory) idézve: , a tér visszaállítása a kritikai társadalomelméletbe" ma fantasztikus méreteket ölt. Az amerikai intellektuális nyelvezetben a történetiségnek, ill. az idóbeliségnek a XX. századra oly jellemzô egyeduralma az utóbbi idớben megtört. Olyan teoretikusok, mint pl. John Berger, Louis Althusser, Edward Said újra felfedezik a teret; a geográfia számos analízisben a központba kerül.

Elképzelhetô, hogy újra megerósödik a foldrajznak egyfajta - a társadalom-és a természettudomanyok közötti - szintetizáló szerepét hangoztató vélemény?

Én ilyen, tudományok kỏzötti szintetizáló szerepben egyáltalán nem hiszek. Azt viszont rendkívül fontosnak tartanám, hogy a természet- és a társadalomföldrajz kapcsolatban maradjon egymással. E véleményemért folyamatosan kritizálnak, egyrészt azok a természetföldrajzosok, alkik felhagytak a humán geográfia mûvelésével, másrészt azok a politikai földrajzzal foglalkozó barátaim, akik nosztalgikusnak tartanak. Szerintem pedig ennek, a geográfia két nagy ága közti kapcsolatnak a fenntartása többé nem nosztalgia - nagyon is pragmatikus politikai indoka van. Természet és társadalom szétválasztása egyértelmứen romboló hatású. Éppen ez okozta, hogy a környezetrốl való gondolkodásunk krízisbe került, ez nyitott utat a társadalom által okozott környezeti katasztrófákhoz. Azt gondolom, hogy az ember által megfigyelt, ,,megtapasztalt" tájat kutató földrajz az a tudományág, amely képes arra, hogy az eddigieknél érzékenyebb értelmezését adja társadalom és természet viszonyának.

Nálunk sokaknak az a véleménye, hogy - az empírikus vizsgálatok folytatása mellett - jóval nagyobb energiát kellene fordítanunk elméleti kutatásokra, hogy az amerikai földrajznak éppen az elméleti gazdagsága a leginkább követésre méltó. Egyetért ezzel?

Természetesen az elméletek rendkívül fontosak, de nem mindegy, milyen elméletrốl van szó. Az 1960-as években az Amerikai Egyesült Államokban kísérletet tettek arra, hogy olyan geogrăfiát alkossanak, amit tudományosnak tartanak az emberek. Csakhogy ez a , tudományos földrajz" az elméletnek egy nagyon sajátságos verzióját jelentette - pozitivista volt. Az USA-ban mindenesetre kimondottan a technokrata igényekhez igazodott. Arra szolgált, hogy megtudjuk, hogyan telepíthetố pl. egy áruház a legkisebb költségekkel, s milyen módon tartható a profit a legmagasabb szinten. Bizonyos értelemben tehát a geográfia egy telepítési technológiává vált. 
Legalábbis azzá akart válni, noha sohasem sikerült kivívnia olyan fontos szerepet, mint amilyenre törekedett.

Meg kell azonban jegyeznem, hogy a földrajz fơ áramlatát valószínúleg napjainkban is ez a pozitivista ,tudományos vízió" uralja. Ennek határterülete ma a földrajzi információs rendszer. A GIS tiszta technológia, ami bizonyos értelemben erốsíti a földrajzot: a Nemzeti Tudományos Alapítvány több millió dollárt adományoz országszerte GIS-centrumok felállítására az egyetemeken. Ugyanakkor az ott képzett hallgatókat a Defend's Mapping Agency, a CIA, általában véve a hadsereg, a privát vállalatok stb. alkalmazzák - innen pedig nincs visszatérés a földrajz mûvelésének intellektuális tevékenységéhez. A GIS egyértelmũen technikák halmaza, melyekkel bárki rendelkezhet, $\mathrm{s}$ azt hiszem a geográfusok a jövớben nem fogják ellenổizni ezt a technológiát. Így e tendencia automatikusan elvezethet a pozitivista, technokrata szemléletmód gyengüléséhez.

A földrajzi teóriáknál maradva, számomra sokkal biztatóbbnak tủnnek a társadalomelméletek terén elért eredmények. Az 1970-as években a feminista, marxista, radikális irányzatok épp a technokrata látásmódot tagadták meg nagyon határozottan. Megkiséreltek létrehozni egy ún. releváns, mondanivalóval bíró geográfiát. Olyan földrajzot, ami szegénységrổl, faji megkülönböztetésrổl, városi szegregációról szól. És ez egy olyan földrajz volt, amelyet az 1970-es évek elején az elméletek keresése jellemzett.

Ha jól tudom, Ön egyike azon kevés férfi kutatóknak, akik nyíltan kiállnak a feminista földrajz mellett. Mára nemcsak a Rutgers Egyetemen, de szerte az országban önálló nókutatási tanszékek müködnek, a geográfus kollégák ebben a témában külön kurzusokat indítanak. Tulajdonképpen mivel magyarázható ennek az irányzatnak a jelentổs térhóditása?

Valóban azt gondolom, hogy a legérdekesebb munkák közül jónéhány ma a feminista geográfia terén születik. Az ide sorolható kutatások az USA-ban és Nagy-Britanniában az 1960-as évek végén, az 1970-es évek elején jelentek meg, különösen az elöretörô feminista, de az emberi jogi, háborúellenes, környezetvédelmi és szocialista mozgalmak által is ösztönözve: A tudományos ortodoxitással szembeni feminista és szocialista kihívások erôteljesen összefonódtak, részét képezve a földrajz már korábban említett, átfogóbb radikalizálódásának. Ennek során fốleg az kapott hangsúlyt, hogy a geográfiai kérdések a társadalmi környezetükbe ágyazódnak be, hogy az állítólag tárgyilagos, ,,objektív" földrajzkutatás nem lehetséges, de - amennyiben az ilyen kutatás a status quo-t erôsíti meg - nem is kívánatos.

Mivel a feminista munkák elôl a tradicionális folyóiratok túlnyomó része elzárkózott, a korai feminista analízisek némelyikét az ,,Antipode” c., az USA-ban és Nagy-Britanniában kiadott radikális folyóiratban, vagy ami még gyakoribb, egyedileg publikálták. Azon túl, hogy dokumentálták a nő̉k felháborítóan alacsony arányát az egyetemi-fổiskolai földrajzban, valamint tartós marginalizálódásukat a diszciplínán belül, a feministák (elsốsorban, de nem kizárólagosan) az urbán problémákra összpontosították figyelemreméltó kutatásaikat. Olyan szerzốk, mint Linda McDowell, Suzanne Mackenzie, Jo Foord és Gerda Wekerle hozzákezdtek, hogy feltárják, milyen módon jut kifejezésre a nemek közti különbség a városi térszerkezetben; rávilágítottak, hogy a termelés mellett a társadalmi reprodukció mennyire fontos tényezóje az urbánus tér kialakításának; megvizsgálták a nớk vezetố szerepével jellemezhetổ helyi közösségek és mozgalmak struktúráját; bemutatták a nók helyét a környezetvédelmi mozgalmak szervezésében. 
De a kezdetben együtt haladó feminista és szocialista geográfia útja határozottan szétvált dz 1970-es években. Mi volt ennek az oka?

A feminista kutatásoknak mind a földrajz uralkodó irányzatán, mind a radikális alternatívákon belüli politikai marginalizálódása, valamint a megfelelő elmélet akkori hiánya egyaránt lhozzájárultak ahhoz, hogy a feminizmus elmaradt a fejlôdésben. Nem tudott elterjedni, és ezạltal jelentốs befolyást gyakorolni a diszciplína egészére úgy, mint azt a marxista irányzat tette. A marxizmusnak természetesen volt egy megalapozott, felhasználható, megvitatható, kétségbe vonható, jelentổs elmélete. Nem véletlen tehát, hogy az 1970-es évek végére a marxista kutatások nagyarányú szellemi erốvé fejlôdtek a földrajzban, dominánssá válva a humángeográfiai határterületek nagy részén. Ezzel szemben a feminista földrajz saját elmélete megteremtéséért küzdött. Átütố sikert azonban nem ért el, mint ahogy nem kapcsolódott igazán jól az 1970-es évek és az 1980-as évek elejének átfogóbb feminista vitáihoz sem.

Ez a helyzet viszont az 1980-as évek végén megváltozott, és mára a feminista kutatás nagyobb szellemi vonzerövel rendelkezik, mint a marxizmus. Ez részben a társadalomelmélet különféle irányzatainak megjelenésébốl, valamint a marxizmussal szemben fellépó kritikai megközelítésból (és nyîlt politikai támadásból) fakad, de ami még fontosabb, a feminizmusban rejlố áj §zzellemi és politikai erổt tükrözi. A konzervatív kormányok Nagy-Britanniában és az USA-ban az 1980-as évek során kitartó támadást indítottak a nôk ellen, elsöpörve a nehezen kiharcolt eredményeket, ide értve az abortuszjogokat, bizonyos szociálpolitikai intézkedéseket, az anyasággal, ill. a gyermekgondozással foglalkozó törvénykezést és a munkalehetôségek egyenlôségét. Gyakran széttöredezve és háttérbe szorultan ugyan, de a feminista ,,mozgalom” olymértékben maradt életképes politikai erô az 1980-as évek során, ahogy a szocialista és más mozgalmak nem voltak képesek. A tudomány világában maradva: a feminista geográfusok sikeresen kapcsolódtak azokhoz az érdekfeszítổ feminista kutatásokhoz, amelyek más társadalomtudományok, a kulturális és humán szféra, s fóleg a posztmodernizmus területén születtek.

Mivel magyanázza, hogy a posztmodernizmus különösen fontossá vált a feminista földrajz számára, s hogyan jellemezné a két irányzat kapcsolatát?

A posztmodern gondolkodás egyrészt a ,,modernista” megközelítések egész sorának elutasít'ását Ígérte, a tradicionáis irodalomtudomány szövegközpontúságától a marxista, strukturalista ês pozitivista ,,metaelméletekig”; valójában tehát mindannak tagadását, ami a materializmus tágan értelmezett fogalmába tartozik. Másrészt, a posztmodern irányzat az idôn túl a teret fogadja el a társadalmi tapasztalat viszonyrendszereként. Ebben a kettôs értelemben pedig úgy tūnik, a posztmodernizmus - Liz Bondi megfogalmazásával élve - ,teret ígér a nốknek". A korábbi csoport mellett a feminista geográfusok egy új generációja terjeszti ki szellemi befolyását a diszciplinán belül: többek között Gerry Pratt, Julie Graham, Cindi Katz, Liz Bondi, Sallie Marston és Ruth Fincher sorolhatók ide. Egy új, a feminista földrajznak szentelt folyóirat (Gender, Place and Culture: A Journal of Feminist Geography) kerül kiadásra 1994-tól.

Bár a posztmodern gondolkodás hozzájárult a feminizmus társadalomtudományokon - és különösen a földrajzon - belüli újra központba állításához, a két irányzat közti viszony nem problémamentes. A posztmodernizmus különbözổ emberek számára különbözổ dolgot jelent, ếs amíg néhány feminista a posztmodern megközelítés feminizmusba való beolvadását szorgalmazza, mások jóval körültekintốbbek, és ragaszkodnak a megkülönböztetéshez. Végül, azt hiszem, a feminizmus egy sokkal koherensebb politikai projekt, mint a posztmodernizmus. Szer- 
vezett politikai választ jelent létezõ társadalmi problémákra, szemben a posztmodern állásponttal, amely életet lehelt ugyan néhány megfeneklett diskurzusba, és oldotta a marxizmus és más tradíciók mindinkább korlátozó merevségét, de túl gyakran vesz idealista fordulatot, azonosítja a nyelvet a létezôvel, és keres egyéni válaszokat súlyos politikai kérdésekre, a kívülállást hirdetve. Politikailag, a posztmodernizmus meglehetôsen sokszor jelenti a szervezés elutasítását, vagy annak tagadását, hogy a szervezódés egyáltalán szükséges.

Mindez egyáltalán nem a posztmodern gondolkodás leértékelése, csupán annak lényeges korlátaira való rávilágítás, így annak kiemelése, hogy a posztmodernizmus a társadalmi osztályokról mélyen hallgat. Ezzel szemben a feminizmus egyik legizgalmasabb aspektusa az, hogy megvan benne a lehetốség egy olyan, sokkal integráltabb társadalomelmélet kifejlesztésére, amely egyúttal politikai erốt is képvisel.

Csakhogy a feminista geográfusok egy része éppen azzal vádolta a neo-marxistákat - köztïk például dzsentrifikációs elméletéért részben Önt is -, hogy kizárólag az osztályviszonyokra, a termelésre helyezik a hangsúlyt. Hogyan látja ezt a fontos nézetkülönbséget?

Marx nagyszerũ meglátása volt, hogy az osztályhelyzet egy határozott - a kizsákmányolás , ,lencséjén” át szemlélt - világképet formál; következésképpen a marxizmus az osztály privilégiumát hangsúlyozta. A feminizmus legartikuláltabb áramlatai nem tagadják ezt az érvet, hanem beépítik abba a gondolatba, miszerint a nemek közti különbözôségek a társadalmi egyenlốtlenségek egyik fontos válfaját alkotják. Tovább bốvítve a kérdést, ma számos társadalomelmélettel foglalkozó szakember és politikai aktivista fontos kutatási feladatnak tartja, hogy megvizsgálja, milyen módon vehetốk számba a különféle lényeges egyenlôtlenségrendszerek: hogyan alkothatunk olyan, politikailag motivált társadalomelméletet, amely figyelembe veszi a faj, a nemzetiség, a szexuális irányultság szerinti, valamint a nemek és az osztályok alapján kialakult társadalmi privilégiumokat is. Egyrészt, feltehetổen el akarunk kerülni egyfajta formátlan relativizmust, melyben a különbözố kiváltságok elméletileg egyenrangúan vannak kezelve: szexuális irányultság és faj, nem és osztály nyilvánvalóan nem, ,egyenlổ' dimenziói az elnyomásnak, bármit is jelentsen az. Ezek meglehetổsen eltérổ módon mû́ködnek, ezért felvetôdik a kérdés: hogyan foglalhatjuk rendszerbe kölcsönkapcsolataikat? Hogyan alkossunk elméletet a köztük lévổ viszonyról? És hogyan tegyük ezt oly módon, hogy az így született elmélet a politika számára is hasznosítható legyen? Ha a tôke és az osztály rajzolja ki a kizsákmányolás kontúrjait, akkor hogyan írják le ugyanezt a kizsákmányolást a nemek és a fajok? Megfordítva, ha azt tételezzük fel, hogy a patriarchátus felelốs a nốk elnyomásáért, akkor hogyan fejezôdik ki az így létrejött egyenlôtlenségrendszerben az osztályok, ill. a fajok közti különbség? Az elmúlt néhány évben a feministák élen jártak az ilyen fajta politikai és társadalmi szintézisek megalkotásában; a feminizmuson belüli viták váltották ki a legnagyobb visszhangot. Donna Haraway, Nancy Hartsock, Sandra Harding és mások munkássága - még ha rendkívül különbözố módon is, de - határozottan nagy befolyásra tett szert a földrajzon belül.

Attól tartok, nálunk számos vonatkozásban azonositják a feminista geográfiát a marxista földrajzzal. Végülis Ön milyennek látja e két irányzat viszonyát, jövóbeni kapcsolatát?

Több mint egy évtizeddel ezelốtt Lydia Sargent ,,A feminizmus és a marxizmus boldogtalan házassága"' (Unhappy Marriage of Feminism and Marxism) miatt siránkozott. Míg az 1970-es évek elejének feminista földrajza szoros kölcsönkapcsolatban állt a geográfiában megjelenô marxizmussal, ma a feminista kutatás sokkal függetlenebb. Olyannyira, hogy extrém esetekben 
még ellenséges is a marxizmussal szemben. A kommunista rezsimek Szovjetunióban és KeletEurópában történt bukásával véglegesen el kellene temetni a marxizmust a sztálinizmussal ossszekavaró nézetet, és újra nyilvánvalóvá kellene tenni, hogy megvan a lehetôsége egy integrált, humánus marxizmusnak. Egy dolog világos: azt a feltételezést, hogy az osztálykülönbségek jelentik a legfontosabb társadalmi egyenlôtlenségeket, ki kell egészíteni a társadalmi szétszakítottság és elnyomás más módjainak elismerésével és tényleges számbavételével. A marxizmustól nem megszabadulni kell, hanem újra kell írni azt. Ahogyan Gayatri Chakravorti Spivak fogalmazta meg: ,,át kell írni a marxizmust a feminizmus pórusaiba". Az osztálykülönbségek a társadalmi tapasztalat alapvetô dimenziójaként és a politikai szervezôdés alapjaként Élnek tovább. És bár sokunk számára - akik az 1960-as évek végén kezdtünk komolyan érdeklốdni a politika iránt - a marxizmus jelentette a belépốt a feminista kutatáshoz, ma a feminizmus veszi át a határozott vezetést más (nem a nemek különbségébốl kiinduló) nézeteknek egy átfogóbb társadalomelméletbe való beintegrálása során.

$\mathrm{Az}$ interjút készítette és fordította: Timár Judit

New Brunswick, 1991. január és 1992..augusztus 
Tér és Társadalom 7. évf. 1993/1-2. 50. p.

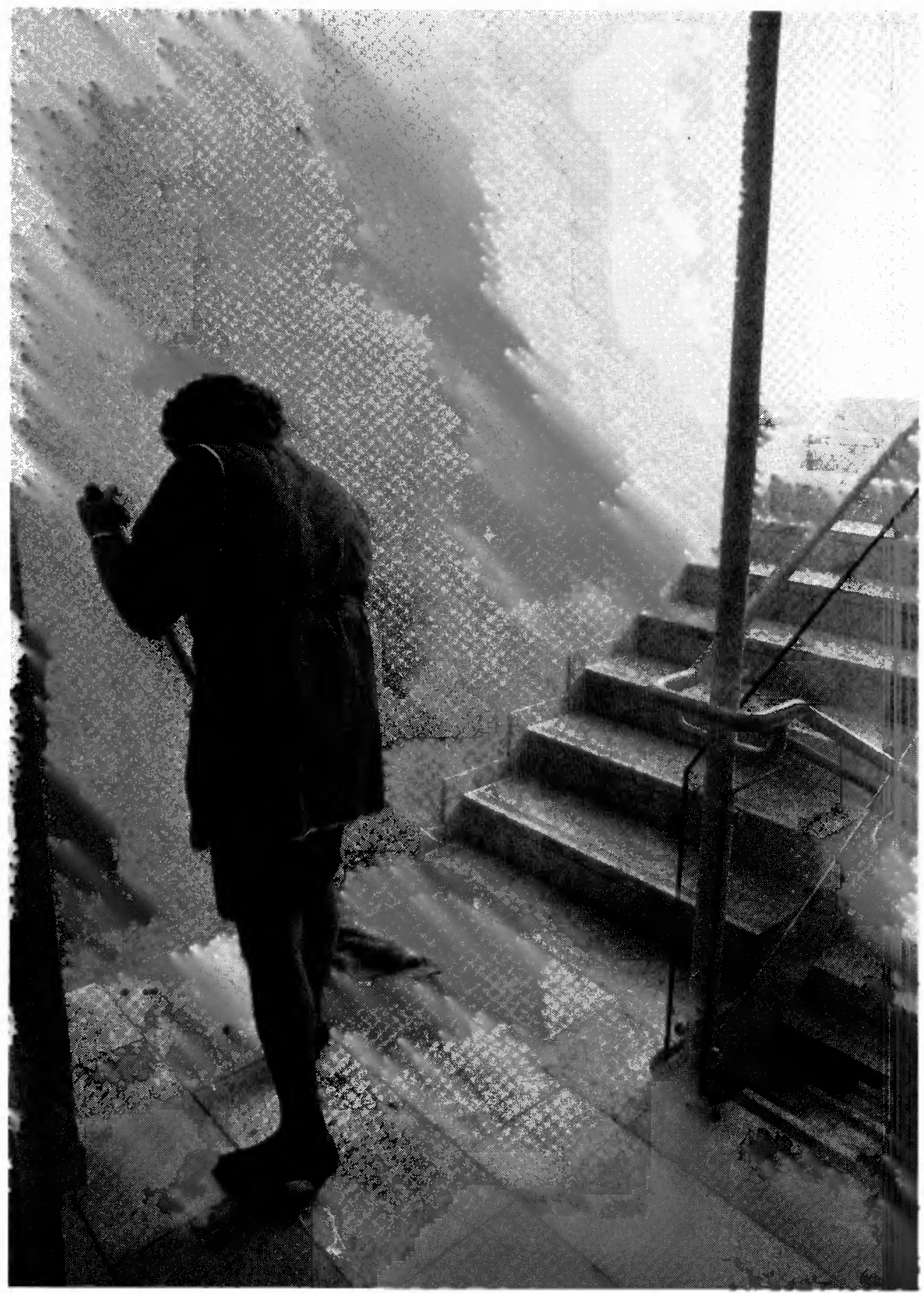

